\title{
COXEN Score 35
}

National Cancer Institute

\section{Source}

National Cancer Institute. COXEN Score 35. NCI Thesaurus. Code C128232.

A score of 35 on the COXEN Sensitivity Scale. 